\title{
New insights into the thermal behavior and decomposition of sodium propionate
}

\author{
Grivel, J.-C.
}

Published in:

Journal of Analytical and Applied Pyrolysis

Link to article, DOI:

10.1016/j.jaap.2018.10.023

Publication date:

2018

Document Version

Peer reviewed version

Link back to DTU Orbit

Citation (APA):

Grivel, J-C. (2018). New insights into the thermal behavior and decomposition of sodium propionate. Journal of Analytical and Applied Pyrolysis, 136, 62-68. https://doi.org/10.1016/j.jaap.2018.10.023

\section{General rights}

Copyright and moral rights for the publications made accessible in the public portal are retained by the authors and/or other copyright owners and it is a condition of accessing publications that users recognise and abide by the legal requirements associated with these rights.

- Users may download and print one copy of any publication from the public portal for the purpose of private study or research.

- You may not further distribute the material or use it for any profit-making activity or commercial gain

- You may freely distribute the URL identifying the publication in the public portal

If you believe that this document breaches copyright please contact us providing details, and we will remove access to the work immediately and investigate your claim. 


\title{
New insights into the thermal behavior and decomposition of sodium propionate
}

\author{
J.-C. Grivel \\ Department of Energy Conversion and Storage, Technical University of Denmark, \\ Frederiksborgvej 399, DK-4000 Roskilde, Denmark
}

\begin{abstract}
Na-propionate $\left(\mathrm{NaC}_{2} \mathrm{H}_{5} \mathrm{CO}_{2}\right)$ was synthesized from $\mathrm{Na}_{2} \mathrm{CO}_{3}$ dissolved in propionic acid. Its thermal behavior was studied in argon and in air. In both atmospheres, two solid-solid phase transitions occur below $250^{\circ} \mathrm{C}$ and are followed by melting near $290^{\circ} \mathrm{C}$. Thermal decomposition begins with release of $\mathrm{CO}_{2}$ attributed to the decomposition of a limited amount of propionyl radicals. Elemental carbon results from this process. This initial reaction is followed by a faster conversion reaction into $\mathrm{Na}_{2} \mathrm{CO}_{3}$ with evolution of 3-pentanone, $\mathrm{CO}_{2}, \mathrm{CO}, \mathrm{CH}_{4}$ and $\mathrm{C}_{2} \mathrm{H}_{4}$ as found during pyrolysis in argon. In air, oxidative decomposition takes place with $\mathrm{CO}_{2}$ and $\mathrm{H}_{2} \mathrm{O}$ as main released gases. The stability of $\mathrm{Na}$-propionate is reduced in air compared to argon atmosphere. The reaction paths are discussed and compared with previously published results on Na-propionate and other propionate metalorganic compounds. The potential of using the low temperature phase transitions of Na-propionate for thermal energy storage $(\Delta \mathrm{H} \approx 245 \mathrm{~J} / \mathrm{g}$ ) was evaluated by submitting samples to 25 heating/cooling cycles.
\end{abstract}

Keywords: Sodium; propionate; decomposition; energy storage

*Corresponding author: jean@dtu.dk 


\section{Introduction}

Na-propionate is a widely used food preservative, which is listed under number 281 in the Codex Alimentarius. Besides this antimicrobial activity, its effects as dietary additive are the topic of intense investigations [1-4] and recent research also found that it plays a role in blood cells differentiation [5]. Considering the variety and importance of the uses of sodium propionate, surprisingly little is known about the thermal decomposition of this key compound. In an early study, Duruz et al. [6] restricted their investigations in the liquid state up to $410^{\circ} \mathrm{C}$. The proposed main decomposition reaction should result in the release of 3-pentanone only, but does not match with the observed simultaneous evolution of $\mathrm{H}_{2} \mathrm{O}$ and $\mathrm{CO}$ as well as minor amounts of $\mathrm{C}_{2} \mathrm{H}_{4}, \mathrm{CO}_{2}$ and 2-butanone. The side reaction:

$$
\mathrm{NaC}_{2} \mathrm{H}_{5} \mathrm{CO}_{2} \rightarrow \mathrm{CH}_{3} \cdot \mathrm{CH}=\mathrm{CO}+\mathrm{NaOH}
$$

was tentatively suggested as an intermediate step leading to other products following reactions between various free radicals such as $\mathrm{CH}_{3}$. and $\mathrm{C}_{2} \mathrm{H}_{5}$. formed by primary ion-catalysed cracking in the melt. A very important conclusion of that work however, is that impurities such as $\mathrm{NaOH}$ and $\mathrm{Cu}$ or $\mathrm{Fe}$ ions can have a drastic effect on the decomposition kinetics and products.

More recently, Masłowska and Więdłocha [7] published a succinct study on the thermal decomposition of Na-propionate as part of an investigation of the thermal behavior of various sodium-based food preservatives in static air. Based on the TG and DTA traces, the following decomposition reaction was proposed:

$$
2 \mathrm{NaC}_{2} \mathrm{H}_{5} \mathrm{CO}_{2} \rightarrow \mathrm{Na}_{2} \mathrm{CO}_{3}+4 \mathrm{H}_{2} \mathrm{O}+5 \mathrm{CO}
$$

Besides the fact that this reaction is not balanced, the evolved gas were not analysed so that the formation of $\mathrm{CO}$ rather than $\mathrm{CO}_{2}$ as a final reaction product in air may be questioned. 
In sharp contrast, the thermal behavior of Na-propionate below its decomposition temperature is well documented (e.g. Mirnaya et al. [8] and references therein). Two solid-solid transitions take place at $197^{\circ} \mathrm{C}$ and $221^{\circ} \mathrm{C}$ preceding melting to an isotropic ionic liquid at $289^{\circ} \mathrm{C}$.

The aim of the present work was to provide a clearer picture of the thermal decomposition behavior of Na-propionate in oxidizing (air) and inert (argon) conditions. Additionally, the reversibility of the low temperature transitions upon temperature cycling were studied to evaluate the potential of Na-propionate in view of possible exploitation in thermal energy storage applications.

\section{Experimental details}

The samples were synthesized by dissolving $200 \mathrm{mg}$ of anhydrous $\mathrm{Na}_{2} \mathrm{CO}_{3}$ (Alfa Aesar, 99.997\% purity) into $4 \mathrm{ml}$ propionic acid (Alfa Aesar, 99\%). After slow evaporation on a hot plate set to $50^{\circ} \mathrm{C}$, the resulting white mass was crushed into a powder that was used without further purification.

Simultaneous Thermogravimetry and Differential Thermal analysis (TG-DTA) measurements were performed in a model STA $449 \mathrm{C}$ from Netzsch at a heating rate of $5{ }^{\circ} \mathrm{C} / \mathrm{min}$ up to $1000^{\circ} \mathrm{C}$ under argon flow $\left(0.5 \mathrm{ppm}\right.$ residual $\left.\mathrm{O}_{2}\right)$ or technical air $\left(20.9 \% \mathrm{O}_{2}\right.$, rest $\left.\mathrm{N}_{2}\right)$ both provided by AGA A/S, with a flow rate of $40 \mathrm{~m} / / \mathrm{min}$ at normal pressure. The crucibles $(6 \mathrm{~mm}$ diameter and 3 $\mathrm{mm}$ depth, i.e. $85 \mu \mathrm{l})$ consisted of alumina. Buoyancy corrections were applied based on data recorded on empty crucibles but otherwise similar experimental conditions. For the measurements, the sample mass was of $11.5 \pm 0.3 \mathrm{mg}$. The powders were not compacted. $\alpha$ $\mathrm{Al}_{2} \mathrm{O}_{3}$ powder (48 mg) was used as reference. Reproducibility was assessed by performing 3 measurements in each atmosphere and it was found that the standard deviation on mass loss amounts to about $0.2 \%$. 
A Bruker Tensor 27 spectrometer coupled to the exhaust line of the TG-DTA device by a transfer line heated to $200^{\circ} \mathrm{C}$ was used for recording Fourier transform infra-red (FTIR) spectra of the evolved gases. FTIR spectra were also recorded on the solid residues of samples heated in the TG-DTA at a rate of $5{ }^{\circ} \mathrm{C} / \mathrm{min}$ and air quenched by opening the furnace in order to examine the evolution of the decomposition products. The enthalpy of the low temperature phase transitions was estimated from the DTA peaks (endothermic and exothermic upon heating and cooling respectively) calibration was performed using standard powders consisting of $\mathrm{KNO}_{3}$, $\mathrm{RbNO}_{3}$ and $\mathrm{KClO}_{4}$. X-ray diffraction (XRD) patterns were collected in a Bruker D8 X-ray diffractometer with $\mathrm{CuK}_{\alpha}$ radiation on samples heated to various temperatures at a heating rate of $5^{\circ} \mathrm{C} / \mathrm{min}$ under $\mathrm{Ar}$ or air flow in the TG-DTA and cooled at a rate of $50^{\circ} \mathrm{C} / \mathrm{min}$. The room temperature XRD pattern of the as-prepared Na-propionate powder was recorded in the same instrument. The evolution of microstructural features was observed at low magnification (50x) by hot-stage optical microscopy up to $700^{\circ} \mathrm{C}$ under Ar flow in a HCP901 chamber from INSTEC Ltd calibrated by observing the melting of metal standards (In, $\mathrm{Sn}, \mathrm{Bi}, \mathrm{Zn}$ and $\mathrm{Al}$ ).

\section{Results and discussion}

The XRD pattern of the synthesized powder is plotted in Fig.1. Besides a reflection originating from the sample holder, it exhibits all peaks corresponding to Na-propionate [9]. The FTIR spectrum of the powder obtained after drying the precursor solution is shown in the inset of Fig.1. It corresponds to that of anhydrous sodium propionate [10]. These data confirm that the compound prepared as described in the previous section consist of Na-propionate. Furthermore, the absence of a broad absorption band around $3400 \mathrm{~cm}^{-1}$ in the FTIR spectrum shows that the compound is anhydrous. The separation between the asymmetric and symmetric $\mathrm{CO}_{2}$ stretching 
bands, $\Delta v=136.5 \mathrm{~cm}^{-1}$, is very close to that measured by Kakihana and Nagumo $(\Delta v=134.6$ $\left.\mathrm{cm}^{-1}\right)$.

Figs. $2 \mathrm{a}$ and $2 \mathrm{~b}$ show respectively the TG and DTA traces recorded under argon or air flow on two Na-propionate powder samples from the same batch. The compound appears more stable in argon atmosphere as the main mass loss, which occurs between $420^{\circ} \mathrm{C}$ and $530^{\circ} \mathrm{C}$, is shifted to lower temperature when the powder is heated in air. While the low temperature behavior of the DTA trace (i.e. up to $340^{\circ} \mathrm{C}$ ) is similar in both atmospheres, a strong exothermic peak is registered in air near $500^{\circ} \mathrm{C}$, in contrast to the measurement conducted in argon atmosphere, which results in an endothermic peak in the same temperature range (IV in Fig.2b).

The three endothermic peaks appearing at $195 \pm 2^{\circ} \mathrm{C}, 216 \pm 2^{\circ} \mathrm{C}$ and $284 \pm 3^{\circ} \mathrm{C}$ respectively (I, II and III in Fig. 2b) have been characterized in previous reports $[6,8,11]$. They are due to two successive solid-solid transitions followed by melting. The observed transition temperatures in the DTA traces recorded in air and argon correspond well with previously reported values $[6,8,11]$. Hot-stage microscopy pictures of two Na-propionate powder samples heated under argon and air flow respectively are shown in Fig.3. No morphological differences can be seen between the pictures recorded at $190^{\circ} \mathrm{C}$ and $210^{\circ} \mathrm{C}$, i.e. over the first endothermic reaction. In contrast, shrinking occurs during the second solid-solid transition as can be seen by comparing the pictures recorded at $210^{\circ} \mathrm{C}$ and $250^{\circ} \mathrm{C}$. Finally, melting is evident in relation with the third endothermic reaction (pictures recorded at $290^{\circ} \mathrm{C}$ ). The fact that only little change takes place in the morphology of the powder particles during the first and second solid-state transitions is not surprising, because the room temperature phase and the two high temperature modifications all crystallize in the monoclinic system with very close lattice parameters [9]. 
However, above $300^{\circ} \mathrm{C}$, the behavior of $\mathrm{Na}$-propionate is strongly dependent on the atmosphere. The nearly $100^{\circ} \mathrm{C}$ lower temperature for the onset of mass loss under air flow suggests a significantly higher stability under reducing atmosphere. In argon, the main mass loss, occurring between $400^{\circ} \mathrm{C}$ and $530^{\circ} \mathrm{C}$, appears to take place in a single step. At $530^{\circ} \mathrm{C}$, the overall mass loss amounts to $43.7 \pm 0.1 \%$, which is a little less than the $44.8 \%$ that are theoretically expected for a decomposition from $\mathrm{Na}$-propionate to Na-carbonate $\left(\mathrm{Na}_{2} \mathrm{CO}_{3}\right)$. In contrast, when heated in air, the sample mass starts decreasing significantly already from $320^{\circ} \mathrm{C}$. After an accelerating stage up to about $450^{\circ} \mathrm{C}$, the mass loss slope first decreases prior to accelerating again. The total mass loss at $510^{\circ} \mathrm{C}$, at which temperature a plateau has been reached in the $\mathrm{TG}$ trace, is equal to $44.6 \pm 0.1 \%$, i.e. very close to the theoretical $44.8 \%$ mentioned above. That the TG plateau around $550^{\circ} \mathrm{C}$ corresponds to the formation of $\mathrm{Na}_{2} \mathrm{CO}_{3}$ can indeed be verified in the FTIR spectra recorded on the solid residues left in this temperature range in both air and argon, as well as with the XRD patterns recorded on the same samples (Fig.4).

According to the FTIR evolved gas analysis, the gas species released during the decomposition leading to the formation of $\mathrm{Na}_{2} \mathrm{CO}_{3}$ in argon consist of $\mathrm{C}_{2} \mathrm{H}_{5} \mathrm{COC}_{2} \mathrm{H}_{5}$ (3-pentanone), $\mathrm{CO}_{2}, \mathrm{CH}_{4}$ and $\mathrm{C}_{2} \mathrm{H}_{4}$ (ethylene) as evidenced in Fig. 5. There is no compelling evidence for the presence of $\mathrm{H}_{2} \mathrm{O}$, a significant difference with the data reported for decomposition in the liquid phase at $360^{\circ} \mathrm{C}$ [6], according to which the most abundant evolving gas species are $\mathrm{H}_{2} \mathrm{O}, \mathrm{C}_{2} \mathrm{H}_{5} \mathrm{COC}_{2} \mathrm{H}_{5}$, $\mathrm{CO}, \mathrm{C}_{2} \mathrm{H}_{4}, \mathrm{CO}_{2}$ and $\mathrm{CH}_{3} \mathrm{COC}_{2} \mathrm{H}_{5}$ in decreasing abundance. The formation of 3-pentanone is a standard characteristic of the thermal decomposition of propionate salts [12-20], although in some cases 2-pentanone [21] or a mixture of $\mathrm{CO}_{2}, \mathrm{CO}$ or $\mathrm{H}_{2} \mathrm{O}$ along with traces of $\mathrm{CH}_{3} \mathrm{CH}_{2} \mathrm{COOH}, \mathrm{CH}_{3} \mathrm{CH}_{2} \mathrm{OH}$ or $\mathrm{CH}_{3} \mathrm{CH}_{2} \mathrm{CO}_{2}$ [22,23] were reported for $\mathrm{Y}$ and $\mathrm{La} / \mathrm{Ni} / \mathrm{Ca}$ propionates respectively. 
The reaction leading to the appearance of the symmetrical ketone can be described as:

$$
2 \mathrm{NaC}_{2} \mathrm{H}_{5} \mathrm{CO}_{2} \rightarrow \mathrm{Na}_{2} \mathrm{CO}_{3}+\mathrm{C}_{2} \mathrm{H}_{5} \mathrm{COC}_{2} \mathrm{H}_{5}
$$

And can result from the free-radical mechanism proposed by Hites and Biemann [24]. On the other hand, the presence of $\mathrm{CH}_{4}, \mathrm{C}_{2} \mathrm{H}_{4}, \mathrm{CO}_{2}$ and $\mathrm{CO}$ among the evolved gases suggests that the ligands themselves are prone to fragmentation into smaller molecular units. The exact mechanism for this process is however difficult to determine. It is striking that $\mathrm{CH}_{4}$ and $\mathrm{C}_{2} \mathrm{H}_{4}$ were not observed during the thermal decomposition of previously studied metal propionate salts [12-23]. This particular situation may be related to the more ionic character of liquid Napropionate and/or to the relatively higher decomposition temperature of Na-propionate. Studies on other alkaline element propionates are limited. For Li-propionate and K-propionate, Bui and de Klerk [25,26] assumed the evolution of 3-pentanone without direct analysis. A more recent study by Yoon et al. [27] suggests that $\mathrm{CO}_{2}$ and $\mathrm{C}_{2} \mathrm{H}_{4}$ are released alongside 3-pentanone during the decomposition of Li-propionate in $\mathrm{N}_{2}$. The analysis in that case is however complicated by the fact that Li-propionate only appears as an intermediate decomposition product of Li-ethylene dicarbonate, which itself also releases $\mathrm{CO}_{2}$ and $\mathrm{C}_{2} \mathrm{H}_{4}$ when transforming into Li-propionate. The thermal decomposition of $\mathrm{Rb}$ and $\mathrm{Cs}$ propionates seems to have only been studied as mixed salts with $\mathrm{Fe}$ in view of ferrite compounds manufacture and the evolved gaseous products were not analyzed [28,29].

The fact that the thermal decomposition process of Na-propionate is more intricate than that of e.g. rare-earth or alkaline earth element propionates is further evidenced by a careful inspection of the DTA trace (Fig. 2b), which shows that in Ar a diffuse exothermic effect sets in at $350^{\circ} \mathrm{C}$, at which point the DTA trace goes back to about $0 \mathrm{~mW}$. The endothermic peak (IV in Fig. 2b) corresponding to the main mass loss, is superimposed on this exothermic background. The onset 
of the exothermic reaction is correlated to the appearance of dark particles in the liquid and a dark rim all around liquid areas as shown in Fig. $6\left(368^{\circ} \mathrm{C}\right.$ and $\left.400^{\circ} \mathrm{C}\right)$ as well as to the detection of $\mathrm{CO}_{2}$ as the only evolving gas up to about $430^{\circ} \mathrm{C}$ (Fig. 7). According to Kerr and Lloyd [30], the propionyl radical $\mathrm{C}_{2} \mathrm{H}_{5} \mathrm{CO}$. tends to decompose into $\mathrm{CO}$ and an ethyl radical $\left(\mathrm{CH}_{3} \mathrm{CH}_{2} \cdot\right)$. Assuming that two $\mathrm{CO}$ molecules combine in such a way as to result in $\mathrm{CO}_{2}+\mathrm{C}$, it could be possible to account for the detection of $\mathrm{CO}_{2}$. The dark particles observed in the liquid and/or at its surface, would then consist of carbon. Interestingly, the $\mathrm{CO}_{2}$ gas evolution trace (Fig. 7) presents a minimum at $470^{\circ} \mathrm{C}$ prior to increasing again in parallel with the accelerating stage of the main mass loss. This suggests that the propionyl radical decomposition process becomes slower or even comes to an end, whereas another decomposition mechanism becomes predominant. A careful look at the number of black particles in hot-stage micrographs (Supplementary material, Fig. S1) reveals that the initial process stops between $440^{\circ} \mathrm{C}$ and $460^{\circ} \mathrm{C}$, short before gas bubbles start to appear $\left(463^{\circ} \mathrm{C}\right.$ in Fig. S1). It may be speculated that the residual oxygen $(0.5 \mathrm{ppm})$ present in the Ar gas could play a role in this initial process as it is exothermic and $\mathrm{CO}_{2}$ is released. However, if such was the case, one would expect a similar effect with significantly higher intensity in air and this is clearly not the case. Indeed, the formation of $\mathrm{CO}_{2}$ does not necessitate an external input of oxygen, because the carbonyl radicals already contain 2 oxygen atoms. The exothermic nature of the reaction might simply be related to the instability of the carbonyl radicals, which spontaneously decompose in this temperature range.

The combination of evolving gasses observed during the main mass loss probably results from several reactions taking place simultaneously. These include reaction (3) associated to the endothermic peak IV between $460^{\circ} \mathrm{C}$ and $560^{\circ} \mathrm{C}$. A recent study by Li et al. [31] showed that n- 
butane, which can be considered as resulting from the association of two ethyl radicals, decomposes into a variety of hydrocarbon compounds, the most abundant being $\mathrm{C}_{2} \mathrm{H}_{4}$ and $\mathrm{CH}_{4}$. The ethyl radicals formed during the early stages of Na-propionate pyrolysis may undergo a related decomposition path, although with an onset temperature lower than that of n-butane. However, since the mass loss at $460^{\circ} \mathrm{C}$ is limited to about $2 \%$, the relatively strong signals of $\mathrm{C}_{2} \mathrm{H}_{4}$ and $\mathrm{CH}_{4}$ (Fig. 7), certainly also include contributions from other reactions, the most plausible being the pyrolysis of parts of the produced 3-pentanone itself, which was shown to result in the formation of $\mathrm{CO}$ and propionyl radicals that would then in turn result in more $\mathrm{C}_{2} \mathrm{H}_{4}$ and $\mathrm{CH}_{4}$ [32]. As shown by the hot-stage micrographs $\left(485^{\circ} \mathrm{C}\right.$ in Fig. 6), intense gas bubbles formation occurs during the main mass loss. This process is finished when the mass plateau has been reached (image captured at $536^{\circ} \mathrm{C}$ in Fig. 6). At higher temperature, the black surface layer of the remaining sample is slowly disappearing, most probably as a result of slow oxidation of carbon left from the decomposition process by the residual oxygen present in the carrier Ar gas. This oxidation process may be the main contribution for the broad exothermic effect taking place after the decomposition of Na-propionate into $\mathrm{Na}_{2} \mathrm{CO}_{3}\left(550^{\circ} \mathrm{C}\right.$ to about $800^{\circ} \mathrm{C}$ in Fig.2b).

In air, the situation is rather different. Although an exothermic contribution to the DTA trace sets in at $350^{\circ} \mathrm{C}$ like in the case of $\mathrm{Ar}$ atmosphere (Fig.2b) and is also accompanied by the evolution of $\mathrm{CO}_{2}$ (Fig.8), its intensity is significantly lower. As shown in Fig. $6\left(360^{\circ} \mathrm{C}\right)$, the sample or at least its surface rapidly solidifies, which must prevent the efficient removal of newly formed gas species. A little exothermic DTA peak appears between $430^{\circ} \mathrm{C}$ and $450^{\circ} \mathrm{C}$ (Fig. 2b). It is related to a surge of $\mathrm{CO}_{2}$ evolution (Fig.8) and the whitening of the sample surface (450 ${ }^{\circ} \mathrm{C}$ in Fig.6). These features are characteristic for the oxidation of the residual carbon that formed during the initial stage of decomposition following a process that may be similar to that 
discussed for the case of Ar atmosphere. It can be noted that this exothermic event also matches with the transient accelerating stage of mass loss around $450^{\circ} \mathrm{C}$ in the TG trace (Fig.2a). At this point, the mass loss has reached about 10\%. At higher temperature, an oxidative decomposition process takes place, which is characterized by a strong exothermic effect with a maximum at $510^{\circ} \mathrm{C}$ in the DTA trace (Fig.2b) and detection of mostly $\mathrm{CO}_{2}$ and $\mathrm{H}_{2} \mathrm{O}$ among the evolved gases. It is not clear whether the oxidative decomposition takes place directly or is preceded by pyrolysis processes similar to those identified in the case of $\mathrm{Ar}$ atmosphere, followed by combustion of the decomposition products after release. The presence of some $\mathrm{C}_{2} \mathrm{H}_{4}$ (Figs. 8 and 9) tends to speak in favor of the second version.

In contrast to Ar atmosphere, the main decomposition in air occurs in solid form as shown by the in-situ hot stage microscope images captured at $450^{\circ} \mathrm{C}$ and $520^{\circ} \mathrm{C}$ (Fig. 6). In spite of these differences, it appears that notwithstanding on the reducing or oxidative nature of the atmosphere, Na-propionate is more stable than other propionates metalorganic salts with a decomposition temperature $100^{\circ} \mathrm{C}$ to $150^{\circ} \mathrm{C}$ higher than reported for rare earth propionates [12$16,20-22,33]$ and about $50^{\circ} \mathrm{C}$ higher than in the case of alkaline earth propionates $[18,19]$.

Above $700^{\circ} \mathrm{C}$, the mass of the samples decreases again, both in air and in Ar, reaching total mass losses of $50.0 \%$ and $54.7 \%$ respectively at $1000^{\circ} \mathrm{C}$. These values are lower than the $67.7 \%$ that are theoretically expected for decomposing $\mathrm{Na}$-propionate into $\mathrm{Na}_{2} \mathrm{O}$. Nevertheless, the TG traces have not reached a plateau at $1000^{\circ} \mathrm{C}$, indicating that the decomposition process is not finished yet. No evidence for the presence of $\mathrm{Na}_{2} \mathrm{O}$ was found in the XRD patterns and FTIR spectra of samples heated to $1000^{\circ} \mathrm{C}$. This can be due to several reasons: rapid reformation of $\mathrm{Na}_{2} \mathrm{CO}_{3}$ upon contact with ambient air, formation of intermediate oxycarbonates or evaporation of $\mathrm{Na}_{2} \mathrm{O}$ (as sodium gas and oxygen [34]). The last of these possibilities is the most probable. 
Indeed, Motzfeldt [34] demonstrated that elemental $\mathrm{Na}$ and $\mathrm{O}_{2}$ escape molten $\mathrm{Na}_{2} \mathrm{CO}_{3}$ during the thermal decomposition of the latter and that during the decomposition process, the concentration of $\mathrm{Na}_{2} \mathrm{O}$ at steady-state is of the order of magnitude of $1 \%$, which precludes the detection of $\mathrm{Na}_{2} \mathrm{O}$ by means of XRD or FTIR techniques. The clear evolution of $\mathrm{CO}_{2}$ at high temperature (Fig.7), which is also in agreement with the work of Motzfeldt [34] supports the decomposition of $\mathrm{Na}_{2} \mathrm{CO}_{3}$ into $\mathrm{Na}$ (gas) $+\mathrm{O}_{2}$ (gas) $+\mathrm{CO}_{2}$ (gas). It is interesting to note that the mass loss starts at lower temperature and is occurring faster in Ar than in air. This can be related to a carbothermic effect induced by the larger amount of residual carbon in the $\mathrm{Na}_{2} \mathrm{CO}_{3}$ formed in $\mathrm{Ar}$ [35]. In that case, melting, the occurrence of which is revealed by an endothermic peak with onset at $854^{\circ} \mathrm{C}$ in the DTA traces (Fig. 2b), has an influence on decomposition kinetics that translates into a change of mass loss rate (see TG trace for $\mathrm{Ar}$ in Fig. 2a) and a non-monotonic rate of $\mathrm{CO}_{2}$ evolution above $700^{\circ} \mathrm{C}$ (Fig.7). An acceleration of the mass loss rate is clearly taking place after melting, whereas it was negligible up to that point, again in agreements with previous reports on the thermal decomposition of $\mathrm{Na}_{2} \mathrm{CO}_{3}[34,36]$.

The total enthalpy of the three low temperature phase changes amounts to about $245 \mathrm{~J} / \mathrm{g}(85 \mathrm{~J} / \mathrm{g}$ for the two solid-solid transitions together), values that could be interesting for thermal energy storage applications as they are comparable with the enthalpy reported for neopentyl glycol/pentaerythritol (NPG/PE) systems that also have transitions at temperatures a little higher than $150^{\circ} \mathrm{C}$ and phase change enthalpies of the order of $200 \mathrm{~J} / \mathrm{g}[37,38]$. In order to evaluate the potential of using Na-propionate for such purpose, the stability of the salt and its behavior below the decomposition temperature was tested by subjecting Na-propionate samples to thermal cycling between room temperature and $310^{\circ} \mathrm{C}$. The results from 25 cycles (temperature increasing and decreasing at $5^{\circ} \mathrm{C} / \mathrm{min}$ ) are shown in Fig. 8 and some traces are plotted in Fig. 
$\mathrm{S} 2$. In $\mathrm{Ar}$, the $\Delta \mathrm{H}$ is constant, but in air a clear degradation takes place. It shall be noted that the sample mass used for $\Delta H$ calculations is the sample's original mass. The monotonically decreasing $\Delta \mathrm{H}$ for thermal cycling in air is primarily due to Na-propionate decomposition and therefore to decrease of the actual $\mathrm{Na}$-propionate mass.

\section{Conclusions}

The thermal decomposition of Na-propionate in Ar comprises a first stage resulting in the release of $\mathrm{CO}_{2}$ and in the formation of carbon particles, which could be due to the decomposition of propionyl radicals. This stage is replaced above about $460^{\circ} \mathrm{C}$ by the more familiar decomposition process of metal carboxylates resulting in the formation of the symmetrical ketone 3-pentanone as well as residual solid $\mathrm{Na}_{2} \mathrm{CO}_{3}$. Side reactions, which can involve partial pyrolysis of 3-pentanone and/or ethyl radicals induce the detection of $\mathrm{CH}_{4}, \mathrm{C}_{2} \mathrm{H}_{4}, \mathrm{CO}$ and $\mathrm{CO}_{2}$. It is worth noting that based on the vibrational spectrum provided in [41] no propionyl radicals were detected by evolved gas analysis, involving that they either decompose on the way between the crucible and the FTIR cell or decompose in the molten sample prior to leaving the crucible. In air, the sample solidifies around $70^{\circ} \mathrm{C}$ above the melting point of $\mathrm{Na}$-propionate and oxidative decomposition reactions are predominant, resulting in the release of mostly $\mathrm{CO}_{2}$ and $\mathrm{H}_{2} \mathrm{O}$. Napropionate might be an interesting candidate for thermal energy storage applications owing to its low temperature phase changes associated to the total $\Delta \mathrm{H}$ of nearly $250 \mathrm{~J} / \mathrm{g}$. However, the salt

should be maintained in a non-oxidative atmosphere to avoid progressive decomposition taking place even just a few degrees above its melting temperature.

\section{Acknowledgements}

This work was financially supported by the Technical University of Denmark [internal grant 49632]. 


\section{References}

[1] S.H. Hoseinifar, Y.-Z. Sun and C.M. Caipang, Short-chain fatty acids as feed supplements for sustainable aquaculture: an updated view, Aquaculture Research 48 (2017) $1380-1391$

[2] E.S. Chambers, C.S. Byrne, K. Aspey, Y.J. Chen, S. Khan, D.J. Morrison and G. Frost, Acute oral sodium propionate supplementation raises resting energy expenditure and lipid oxidation in fasted humans, Diabetes Obesity \& Metabolism 20 (2018) $1034-1039$

[3] S. Biswal, D.C. Nayak, K.K. Sardar and G. Sahoo, Improvement of the biochemical and metabolic biomarkers in response to the therapeutic management in kerotic dairy cows, Ezploratory Animal and Medical Research 7 (2017) 87 - 93

[4] U. Agarwal, Q. Hu and B.J. Bequette, Propionate supplementation improves nitrogen use by reducing urea flux in sheep, J. Anim. Sci. 93 (2015) 4883 - 4890

[5] Y. Zhang, J. Maksimovic, B. Huang, D.P. de Souza, G. Naselli, H. Chen, L. Zhang, H., K. Weng, H. Liang, Y. Xu, J.M. Wentworth, N.D. Huntington, A. Oshlack, S. Gong, A. Kallies, P. Vuillermin, M. Yang and L.C. Harrison, Cord blood CD8 ${ }^{+}$T cells have a natural propensity to express IL-4 in a fatty acid metabolism and caspase activationdependent manner, Front. Immunol. 9 (2018) 879

[6] J.J. Duruz, H.J. Michels and A.R. Ubbelohde, Decomposition reactions of sodium propionate, J. Chem. Soc. B 7 (1971) 1505 - 1509

[7] J. Masłowska and M. Więdłocha, Thermal decomposition of some chemical compounds used as food preservatives and kinetic parameters of this process, J. Thermal Anal. Calorim. 60 (2000) $305-312$ 
Journal of Analytical and Applied Pyrolysis / preprint

[8] T.A. Mirnaya, G.G. Yaremchuk and S.V. Volkov, Phase diagrams of binary systems of some alkali propionates, Z. Naturforsch. 48A (1993) 995 - 999

[9] V. Massarotti and G. Spinolo, Crystal data for sodium propanoate: $\mathrm{C}_{2} \mathrm{H}_{5} \mathrm{COONa}$, J. Appl. Cryst. 12 (1979) $613-614$

[10] M. Kakihana and T. Nagumo, Assignment for the infrared spectrum of solid sodium propionate from low-temperature measurements in combination with ${ }^{13} \mathrm{C}$ isotopic shifts, Z. Naturforsch. 42A (1987) $477-484$.

[11] P. Ferloni, M. Sanesi and P. Franzosini, Phase transitions in the alkali $\mathrm{C}_{1}-\mathrm{n}_{\mathrm{C}} \mathrm{C}_{4}$ alkanoates, Z. Naturforsch. 30a (1975) $1447-1454$

[12] J.-C. Grivel, Thermal decomposition of $\mathrm{Ln}\left(\mathrm{C}_{2} \mathrm{H}_{5} \mathrm{CO}_{2}\right)_{3} \cdot \mathrm{H}_{2} \mathrm{O}(\mathrm{Ln}=\mathrm{Ho}$, Er, Tm and $\mathrm{Yb})$, J. Therm. Anal. Calorim. 109 (2012) $81-88$

[13] J.-C. Grivel, Thermal decomposition of yttrium(III) propionate and butyrate, J. Anal. Appl. Pyrol. 101 (2013) 185 - 192

[14] J.-C. Grivel, Thermal decomposition of lutetium propionate, J. Anal. Appl. Pyrolysis 89 (2010) $250-254$

[15] J.-C. Grivel, Thermal decomposition of $\mathrm{RE}\left(\mathrm{C}_{2} \mathrm{H}_{5} \mathrm{CO}_{2}\right)_{3} \cdot \mathrm{H}_{2} \mathrm{O}(\mathrm{RE}=\mathrm{Dy}, \mathrm{Tb}, \mathrm{Gd}, \mathrm{Eu}$ and Sm), J. Thermal Anal. Calorim. 115 (2014) 1253 - 1264

[16] M. Ogawa and $\mathrm{K}$ Manabe, Formation of dilanthanide monoxide tetrapropionate by thermal-decomposition of propionate monohydrate of rare-earth elements (La, Ce, Pr, Nd), Nippon Kagaku Kaishi 5 (1993) 617 - 622

[17] J. Skoršepa, E. Godočíková and J. Černák, Comparison on thermal decomposition of propionate, benzoate and their chloroderivative salts of $\mathrm{Zn}(\mathrm{II})$, J. Thermal Anal. Calor. 75 (2004) $773-780$ 
Journal of Analytical and Applied Pyrolysis / preprint

[18] E. Gobert-Ranchoux and F. Charbonnier, Comportement thermique des propionates hydrates de calcium, strontium et barium, J. Thermal Anal. 12 (1977) 33 - 42

[19] P.A. Barnes, G. Stephenson and S.B. Warrington, The use of TA - GLC - MS as a quantitative specific EGA technique for the investigation of complex thermal decomposition reactions: the thermal decomposition of calcium propanoate, J. Thermal Anal. 25 (1982) $299-311$

[20] L. Ciontea, M. Nasui, T. Petrisor Jr., R.B. Mos, M.S. Gabor, R.A. Varga and T. Petrisor, Synthesis, crystal structure and thermal decomposition of $\left[\mathrm{La}_{2}\left(\mathrm{CH}_{3} \mathrm{CH}_{2} \mathrm{COO}\right)_{6} \cdot\left(\mathrm{H}_{2} \mathrm{O}\right)_{3}\right] \cdot 3.5 \mathrm{H}_{2} \mathrm{O}$ precursor for high- $k \mathrm{La}_{2} \mathrm{O}_{3}$ thin films deposition, Mater. Res. Bull. 45 (2010) 1203 - 1208

[21] M. Nasui, C. Bogatan (Pop), L. Ciontea and T. Petrisor, Synthesis, crystal structure modeling and thermal decomposition of yttrium propionate $\left[\mathrm{Y}_{2}\left(\mathrm{CH}_{3} \mathrm{CH}_{2} \mathrm{COO}\right)_{6} \cdot \mathrm{H}_{2} \mathrm{O}\right] \cdot 3.5 \mathrm{H}_{2} \mathrm{O}$, J. Anal. Appl. Pyrolys is 97 (2012) 88 - 93

[22] A. Kaddouri and C.J. Mazzocchia, Thermoanalytic study of some metal propionates synthsised by sol-gel route: a kinetic and thermodynamic study, J. Anal. Appl. Pyrolysis 65 (2002) $253-267$

[23] M. El Baydi, G. Poillerat, J.-L. Rehspringer, J.L. Gautier, J.-F. Koenig and P. Charlier, J., A sol-gel route for the preparation of $\mathrm{Co}_{3} \mathrm{O}_{4}$ catalyst for oxygen electrocatalysis in alkaline medium, Sol. St. Chem. 109 (1994) $281-288$

[24] A. Hites and K. Biemann, On the mechanism of ketonic decarboxylation. Pyrolysis of calcium decanoate, J. Amer. Chem. Soc. 94 (1972) 5772 - 5777

[25] H.L. Bui and A. de Klerk, Lithium $\mathrm{C}_{1}-\mathrm{C}_{12} n$-alkanoates: thermal behavior from $-30^{\circ} \mathrm{C}$ to $600^{\circ} \mathrm{C}, \mathrm{J}$. Chem. Eng. Data 58 (2013) 1039 - 1049 
[26] H.L. Bui and A. de Klerk, Thermal behavior of potassium $\mathrm{C}_{1}-\mathrm{C}_{12} n$-alkanoates and its relevance to Fischer-Tropsch, J. Chem. Eng. Data 59 (2014) 400 - 411

[27] T. Yoon, M.S. Milien, B.S. Parimalam and B.L. Lucht, Thermal decomposition of the solid electrolyte interphase (SEI) on silicon electrodes for lithium ion batteries, Chem. Mater. 29 (2017) $3237-3245$

[28] M. Gupta and B.S. Randhawa, Synthesis of nanosized rubidium ferrite by thermolysis of ferricarboxylate precursors and combustion method, J. Anal. Appl. Pyrolysis 95 (2012) $25-30$

[29] M. Gupta, M. Gupta and B.S. Randhawa, Synthesis of nanosized cesium ferrite by precursors and combustion method: a comparative study, Int. J. Appl. Ceram. Technol. $10(2013) 917-923$

[30] J.A. Kerr and A.C. Lloyd, Kinetics and pressure dependence of the decomposition of the propionyl radical, Trans. Far. Soc. 63 (1967) 2480 - 2488

[31] W. Li, G. Wang, Y. Li, T. Li, Y. Zhang, C. Cao, J. Zou and C.K. Law, Experimental and kinetic modelling investigation on pyrolysis and combustion of $n$-butane and $i$-butane at various pressures, Combustion and Flame 191 (2018) 126 - 141

[32] E.E. Dames, K.-Y. Lam, D.F. Davidson and R.K. Hanson, An improved kinetic mechanism for 3-pentanone pyrolysis and oxidation developed using multispecies time histories in shock-tubes, Combustion and Flame 161 (2014) $1135-1145$

[33] V. Mihalache, M. Secu and J.-C. Grivel, Defect states and room temperature ferromagnetism in cerium oxide nanopowders prepared by decomposition of $\mathrm{Ce}$ propionate, Mater. Chem. Phys. 209 (2018) 121 - 133 
[34] K. Motzfeldt, The thermal decomposition of sodium carbonate by the effusion method, J. Phys. Chem. 59 (1955) $139-147$

[35] J.-W. Kim and H.-G. Lee, Thermal and carbothermic decomposition of $\mathrm{Na}_{2} \mathrm{CO}_{3}$ and $\mathrm{Li}_{2} \mathrm{CO}_{3}$, Metallurgical and Materials Transactions 32B (2001) $17-24$

[36] J.-W. Kim, Y.-D. Lee and H.-G. Lee, Decomposition of $\mathrm{Na}_{2} \mathrm{CO}_{3}$ by interaction with $\mathrm{SiO}_{2}$ in mold flux of steel continuous casting, ISIJ International 41 (2001) 116 - 123

[37] L.F. Cabeza, A. Castell, C. Barreneche, A. de Gracia and A.I. Fernández, Materials used as PCM in thermal energy storage in buildings: A review, Renewable and Sustainable Energy Reviews 15 (2011) $1675-1695$

[38] A. Fallahi, G. Guldentops, M. Tao, S. Granados-Focil and S. van Dessel, Review on solid-solid phase change materials for thermal energy storage: Molecular structure and thermal properties, Appl. Thermal Engineering 127 (2017) 1427 - 1441

[39] Spectral Database for Organic Compounds, SDBSWeb : https://sdbs.db.aist.go.jp (National Institute of Advanced Industrial Science and Technology, 2018)

[40] NIST Chemistry WebBook, SRD 69, https://webbook.nist.gov/chemistry/name-ser/

[41] G. Chettur and A. Snelson, Alkylperoxy and alkyl radicals, 4. Matrix IR spectra and UV photolysis of $\mathrm{C}_{2} \mathrm{H}_{5} \mathrm{O}_{2}$ and $\mathrm{C}_{2} \mathrm{H}_{5}$ radicals, J. Phys. Chem. 91 (1987) 3483 - 3488 


\section{Figure captions}

Figure 1: XRD pattern of the as-prepared powder: $\bullet$ Na-propionate [9], $\bigcirc$ sample holder. Inset: FTIR spectrum of the same powder. The assignment of the absorption bands is based on reference [10] and vertical tick marks indicate the position and relative intensities of the reference pattern. NB: the lowest angle peak has been reduced by a factor 4 to improve the visibility of the other tick marks.

Figure 2: (a) TG traces recorded on Na-propionate powders in air or Ar. (b) Simultaneous DTA traces of the samples in Fig.2a. The insets show details of the low temperature region, highlighting the low temperature phase transitions (left) and the onset of the exothermic effects (right). Exothermic effects upwards.

Figure 3: In-situ, hot stage optical microscope images of Na-propionate powders heated either in argon (left column) or in air (right column). The same magnification was used for all images.

Figure 4: FTIR spectra of samples heated to $525^{\circ} \mathrm{C}$ (in air) or $550^{\circ} \mathrm{C}$ (in Ar) showing the formation of $\mathrm{Na}_{2} \mathrm{CO}_{3}(\bullet)$. Inset: XRD patterns of the same samples confirming the presence of $\mathrm{Na}_{2} \mathrm{CO}_{3}(\boldsymbol{\nabla})$.

Figure 5: FTIR spectrum of the gas phase evolved from Na-propionate heated in $\mathrm{Ar}$ at $5^{\circ} \mathrm{C} / \mathrm{min}$. Spectrum recorded at $516^{\circ} \mathrm{C} . \nabla: \mathrm{CO}_{2}, \nabla: 3$-pentanone, $\mathbf{\square}: \mathrm{CH}_{4}, \triangle: \mathrm{C}_{2} \mathrm{H}_{4}, \diamond: \mathrm{CO}$. The identification of the compounds was based on a comparison with reference patterns $[39,40]$.

Figure 6: In-situ, hot stage optical microscope images of Na-propionate samples heated in argon or in air. The same magnification was used for all images.

Figure 7: Evolution of the intensity of characteristic absorption bands of the detected evolving gas species versus temperature during heating in Ar. The wavenumbers selected for the 
respective traces are: $\mathrm{C}_{2} \mathrm{H}_{4}: 946 \mathrm{~cm}^{-1}, \mathrm{CH}_{4}: 1306 \mathrm{~cm}^{-1}, 3$-pentanone: $1722 \mathrm{~cm}^{-1}, \mathrm{CO}: 2116 \mathrm{~cm}^{-1}$ and $\mathrm{CO}_{2}: 2355 \mathrm{~cm}^{-1}$. The lower curve is the DTG trace.

Figure 8: Evolution of the intensity of characteristic absorption bands of the detected evolving gas species versus temperature during heating in air. The wavenumbers selected for the respective traces are: $\mathrm{C}_{2} \mathrm{H}_{4}: 946 \mathrm{~cm}^{-1}, \mathrm{CO}_{2}: 2355 \mathrm{~cm}^{-1}$ and $\mathrm{H}_{2} \mathrm{O}: 1507 \mathrm{~cm}^{-1}$. NB: The intensity of the $\mathrm{C}_{2} \mathrm{H}_{4}$ signal has been multiplied by a factor 10 for ease of visualization. The lower curve is the DTG trace.

Figure 9: FTIR spectrum of the gas phase evolved from $\mathrm{Na}$-propionate heated in air at $5^{\circ} \mathrm{C} / \mathrm{min}$. Spectrum recorded at $507^{\circ} \mathrm{C} . \nabla: \mathrm{CO}_{2}, \triangle: \mathrm{C}_{2} \mathrm{H}_{4}, \bullet: \mathrm{H}_{2} \mathrm{O}$. The wavenumbers selected for the respective traces are: $\mathrm{C}_{2} \mathrm{H}_{4}: 946 \mathrm{~cm}^{-1}, \mathrm{H}_{2} \mathrm{O}: 1558 \mathrm{~cm}^{-1}$ and $\mathrm{CO}_{2}: 2355 \mathrm{~cm}^{-1}$.

Figure 10: Total enthalpy for the 3 low temperature phase transitions corresponding to peaks I, II and III in Fig.2b for Na-propionate samples cycled 25 times between $30^{\circ} \mathrm{C}$ and $310^{\circ} \mathrm{C}$ in argon or in air. The solid symbols are for heating and the open symbols correspond to cooling. 


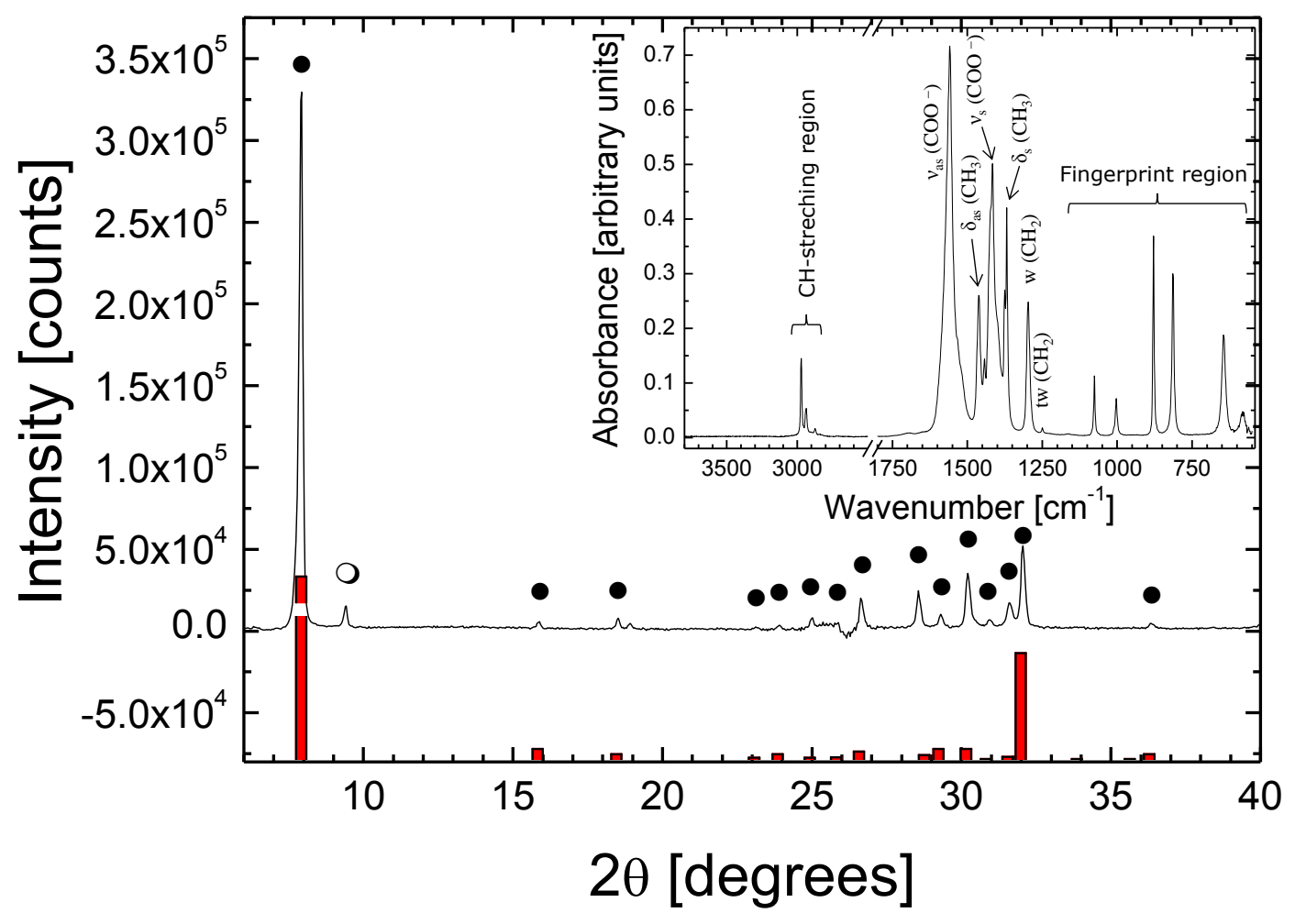

Figure 1 


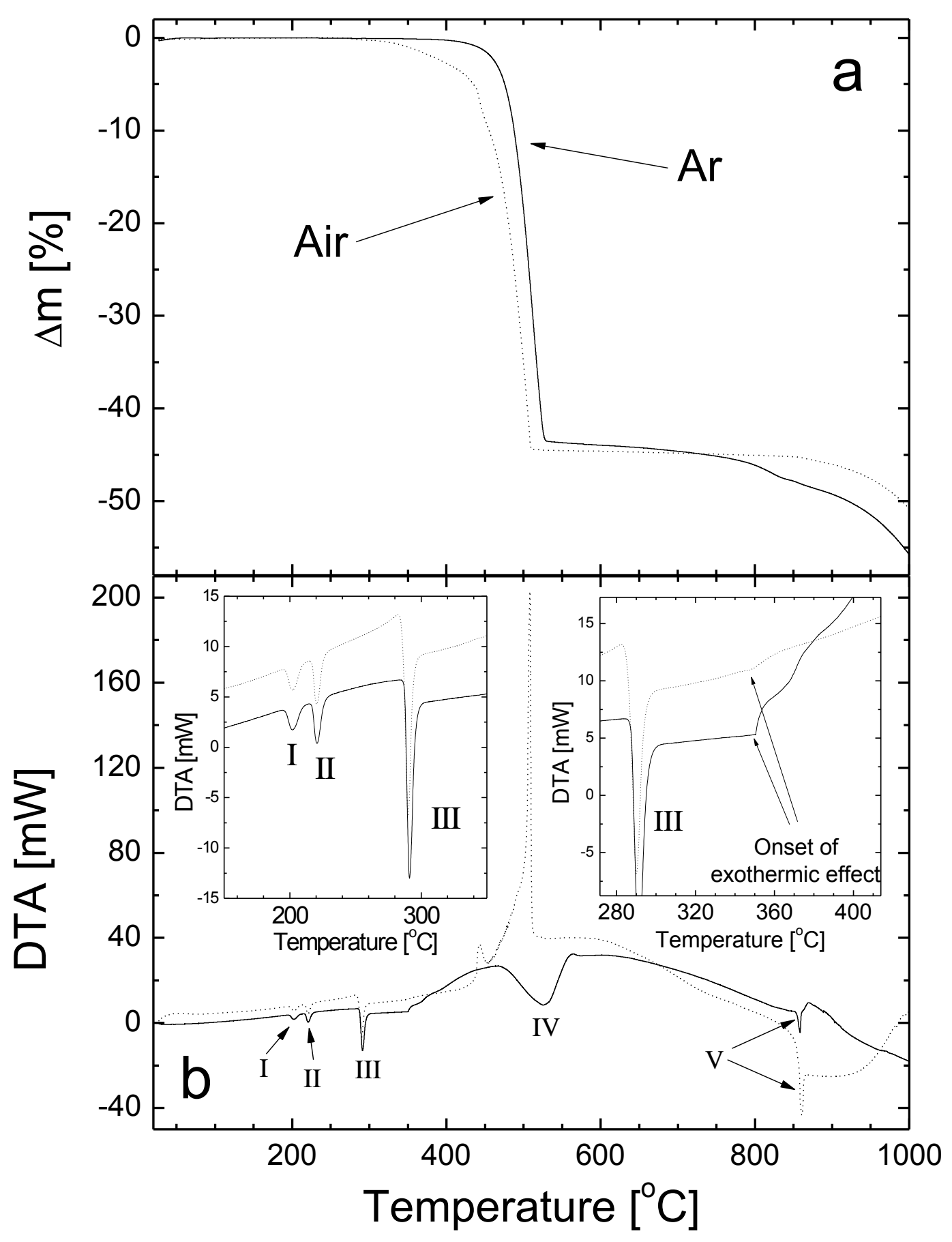

Figure 2 


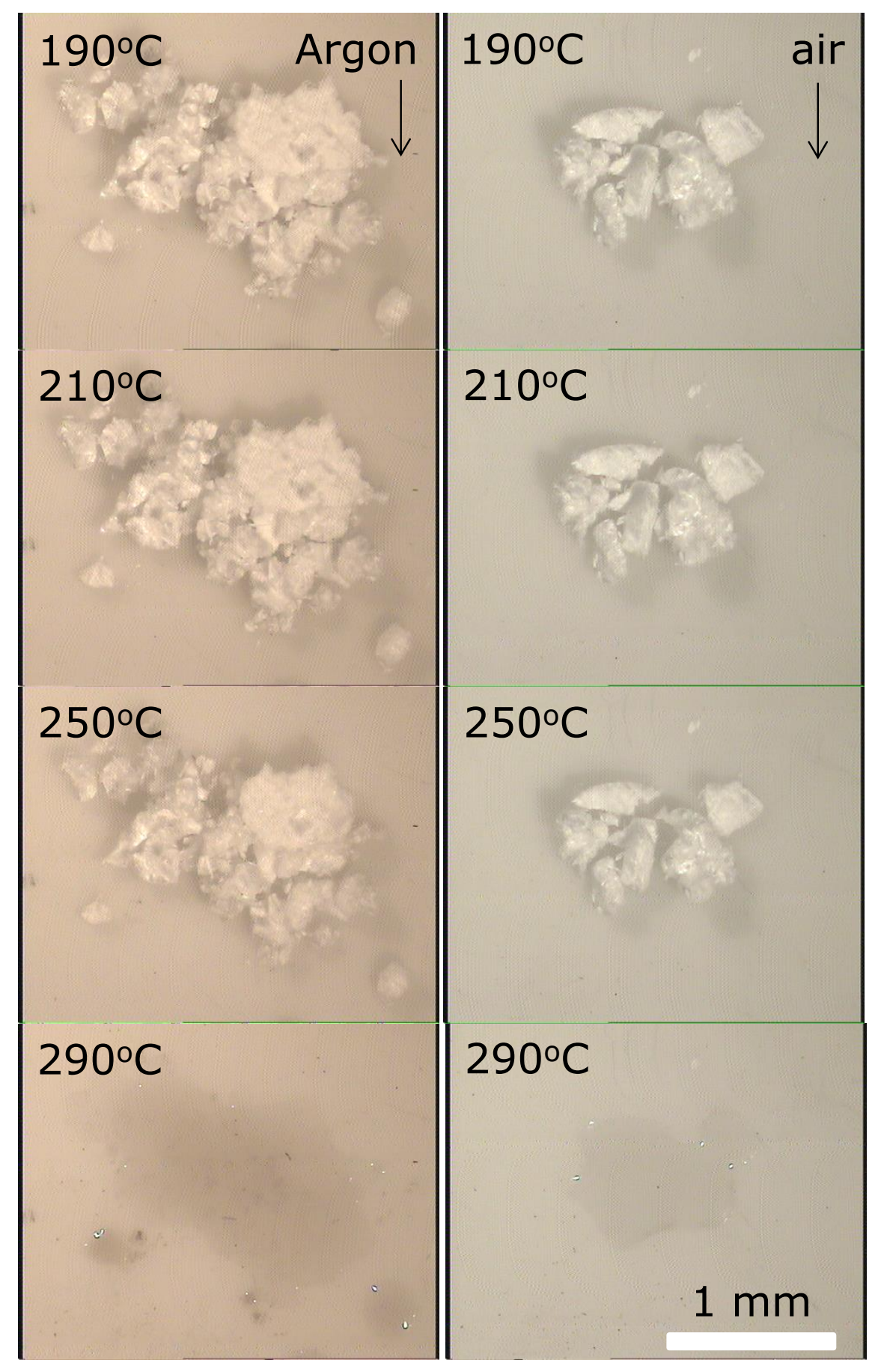

Figure 3 


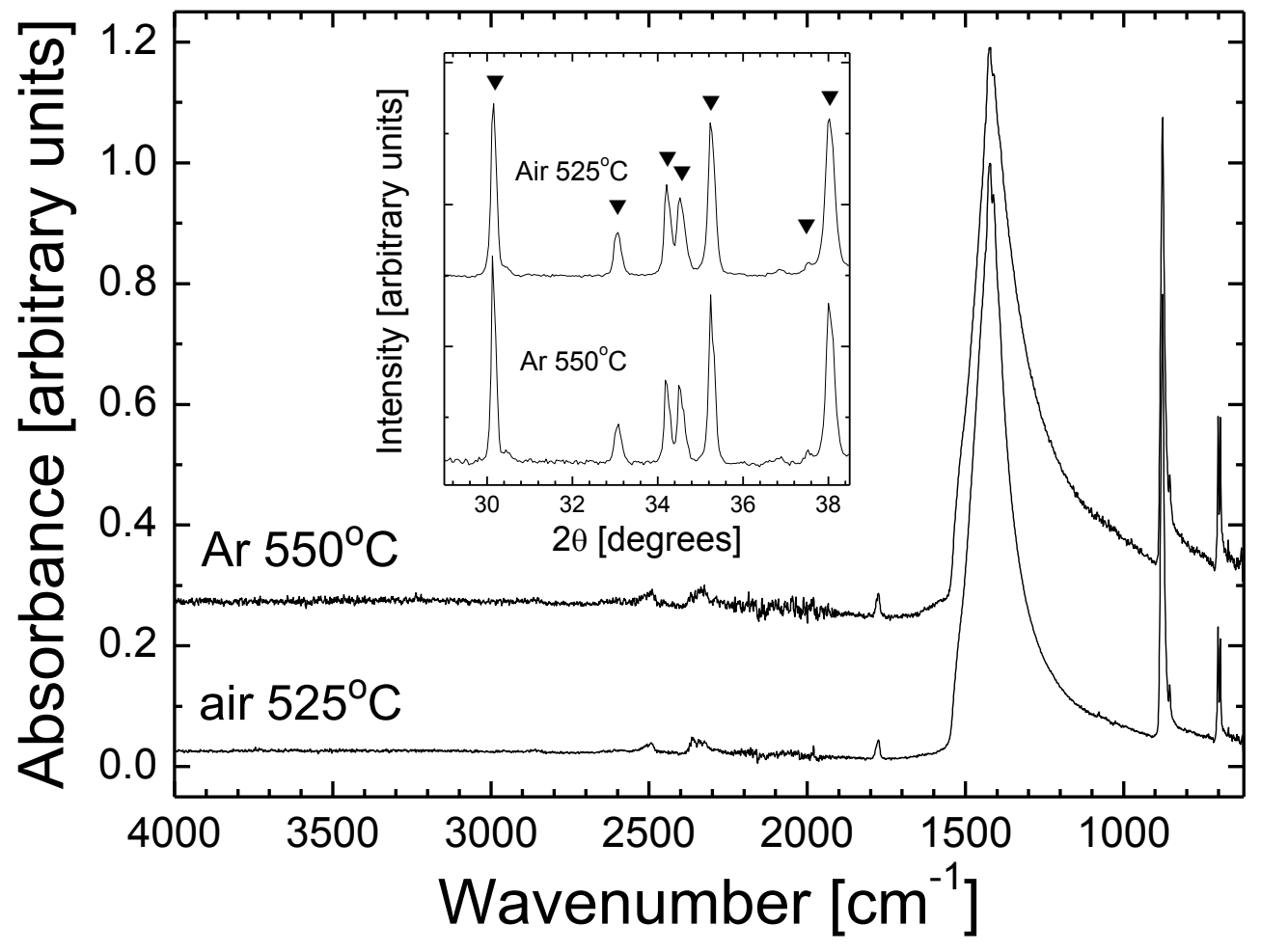

Figure 4 
Journal of Analytical and Applied Pyrolysis / preprint

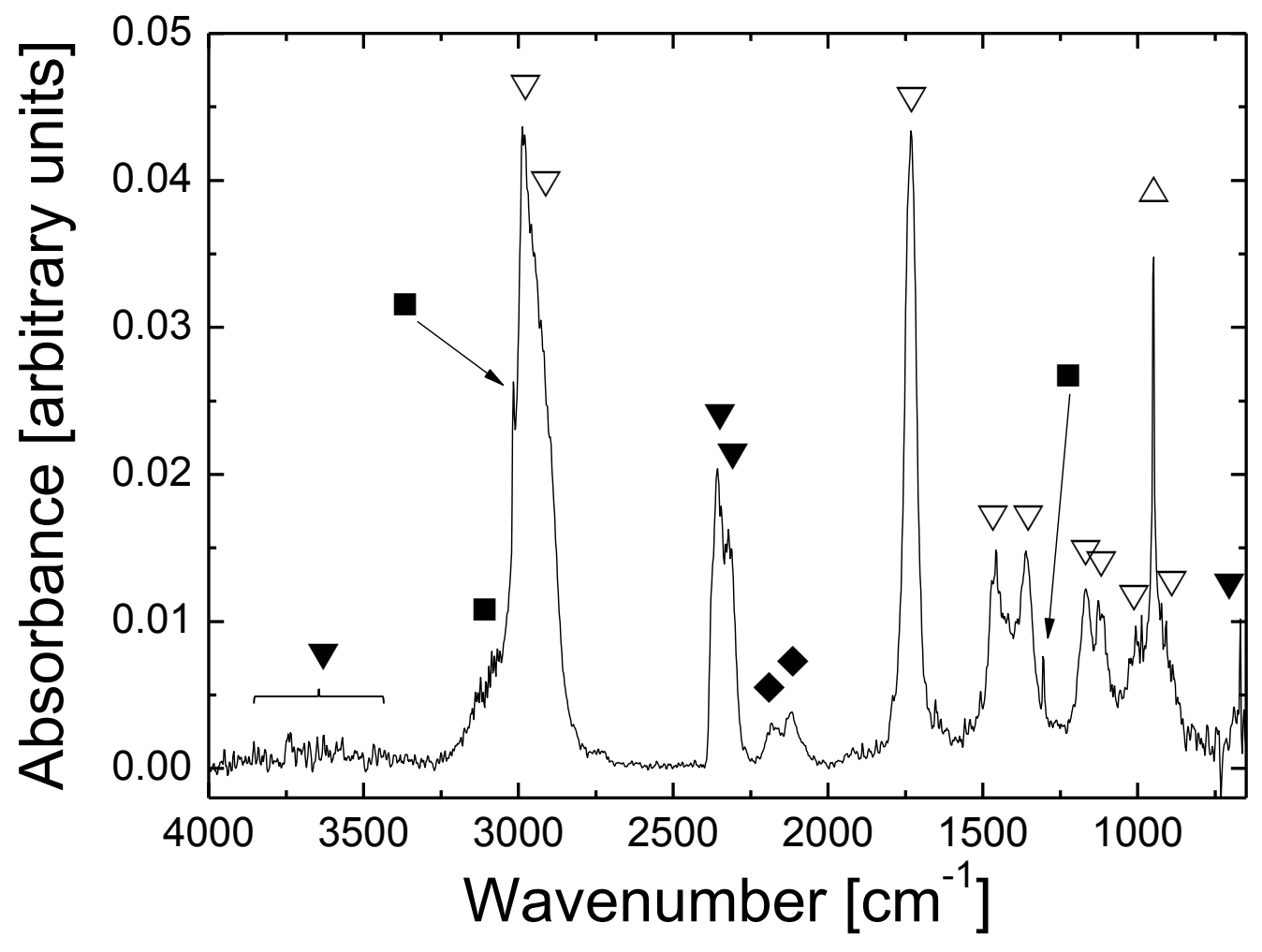

Figure 5 


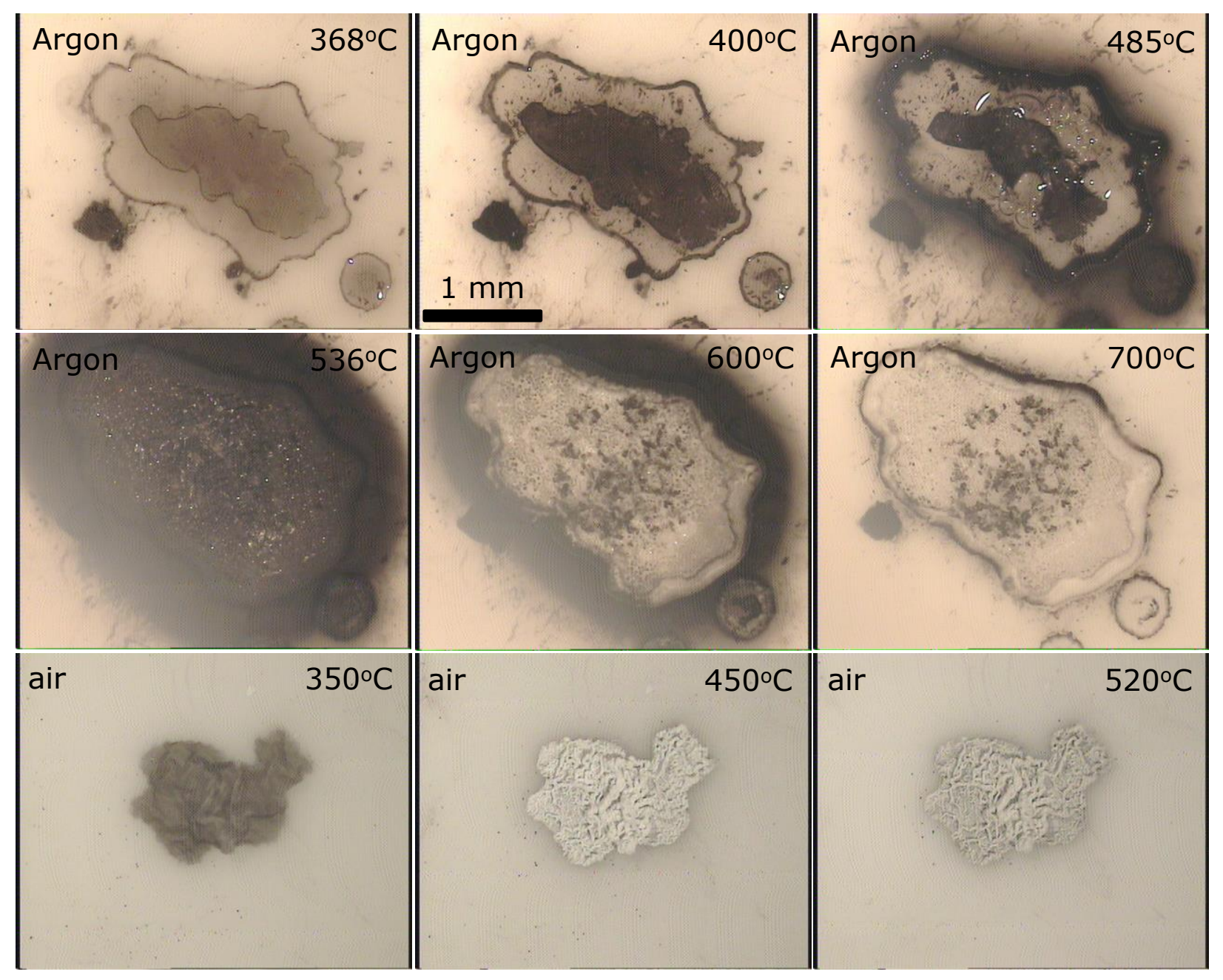

Figure 6 


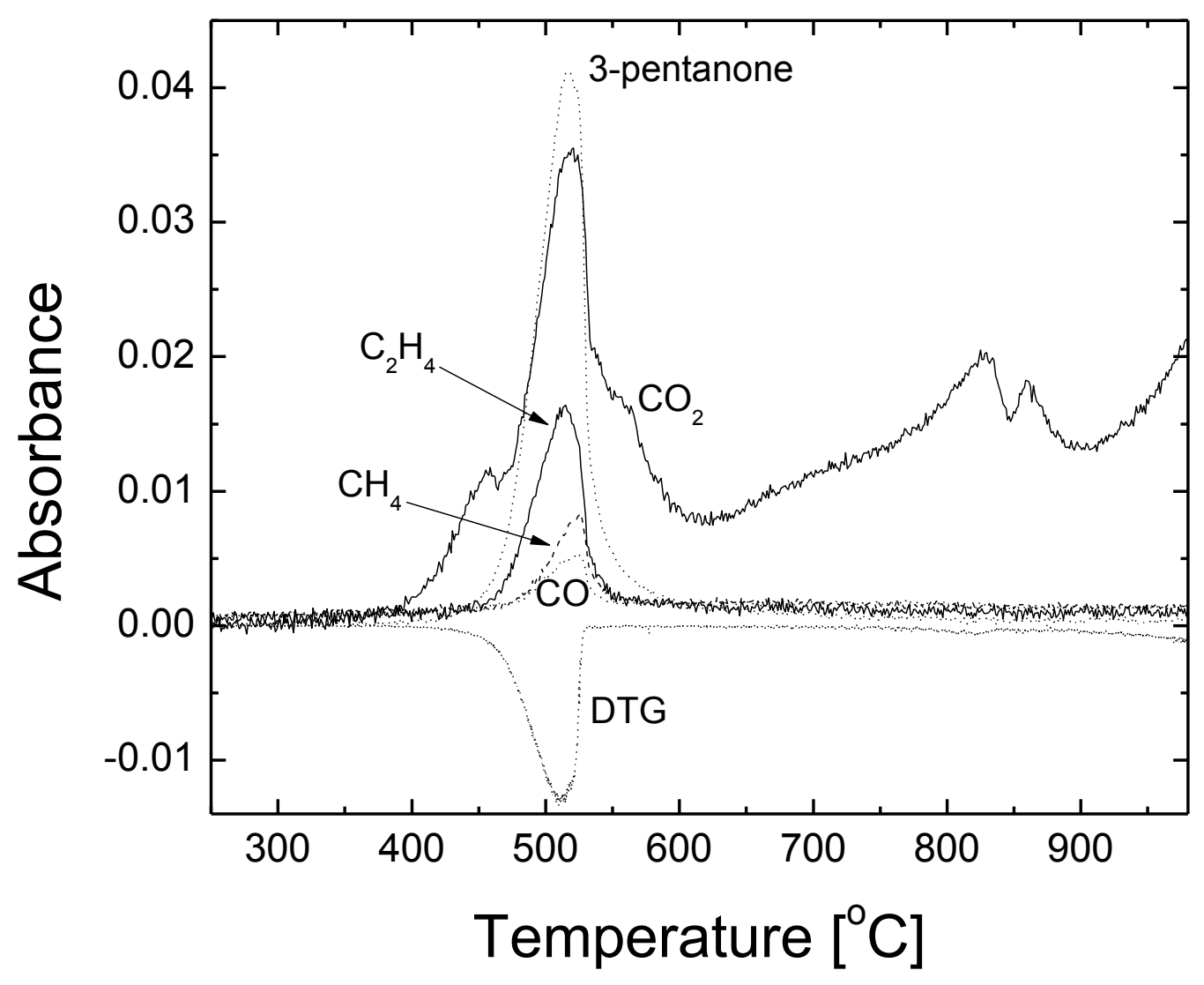

Figure 7 
Journal of Analytical and Applied Pyrolysis / preprint

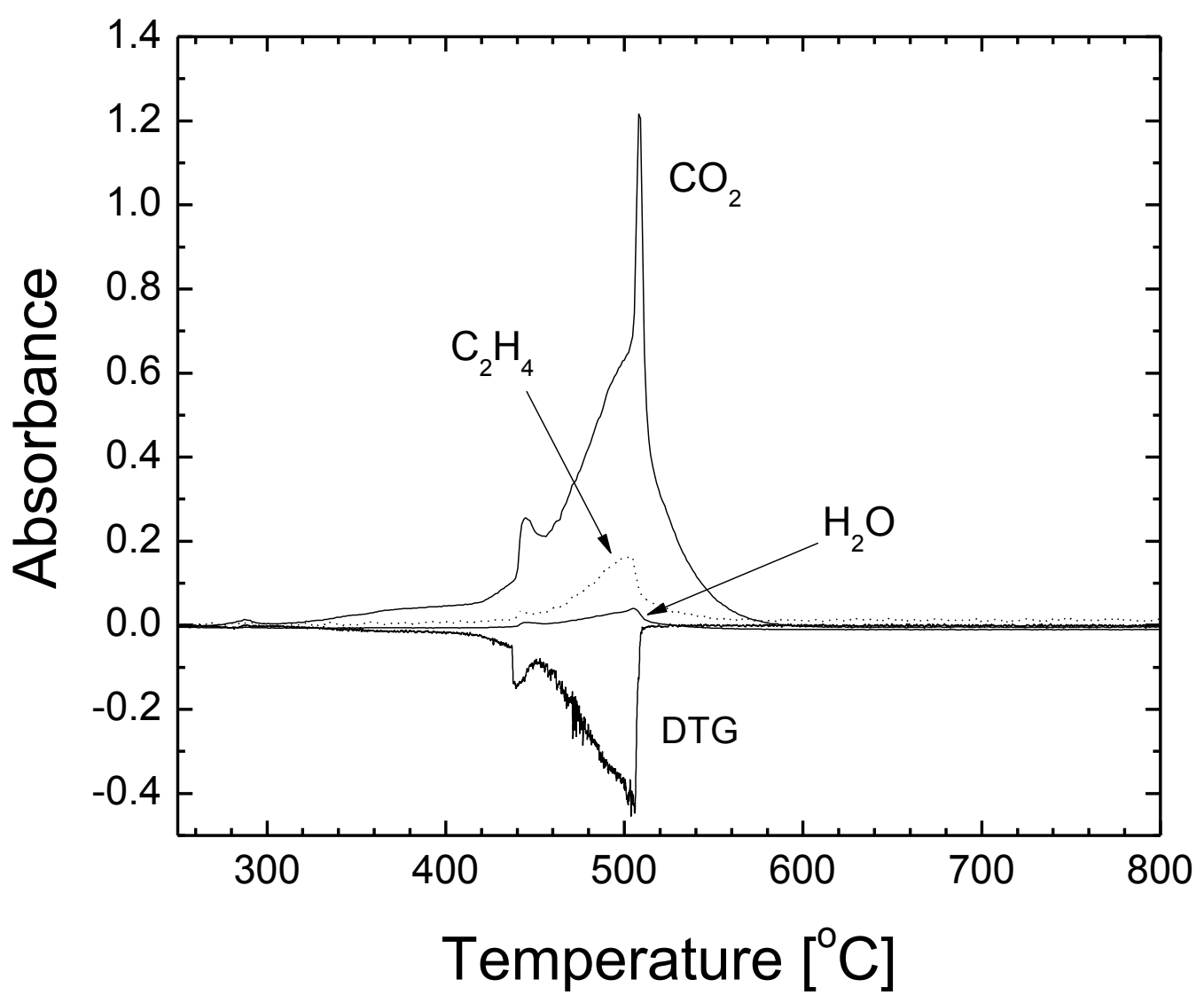

Figure 8 


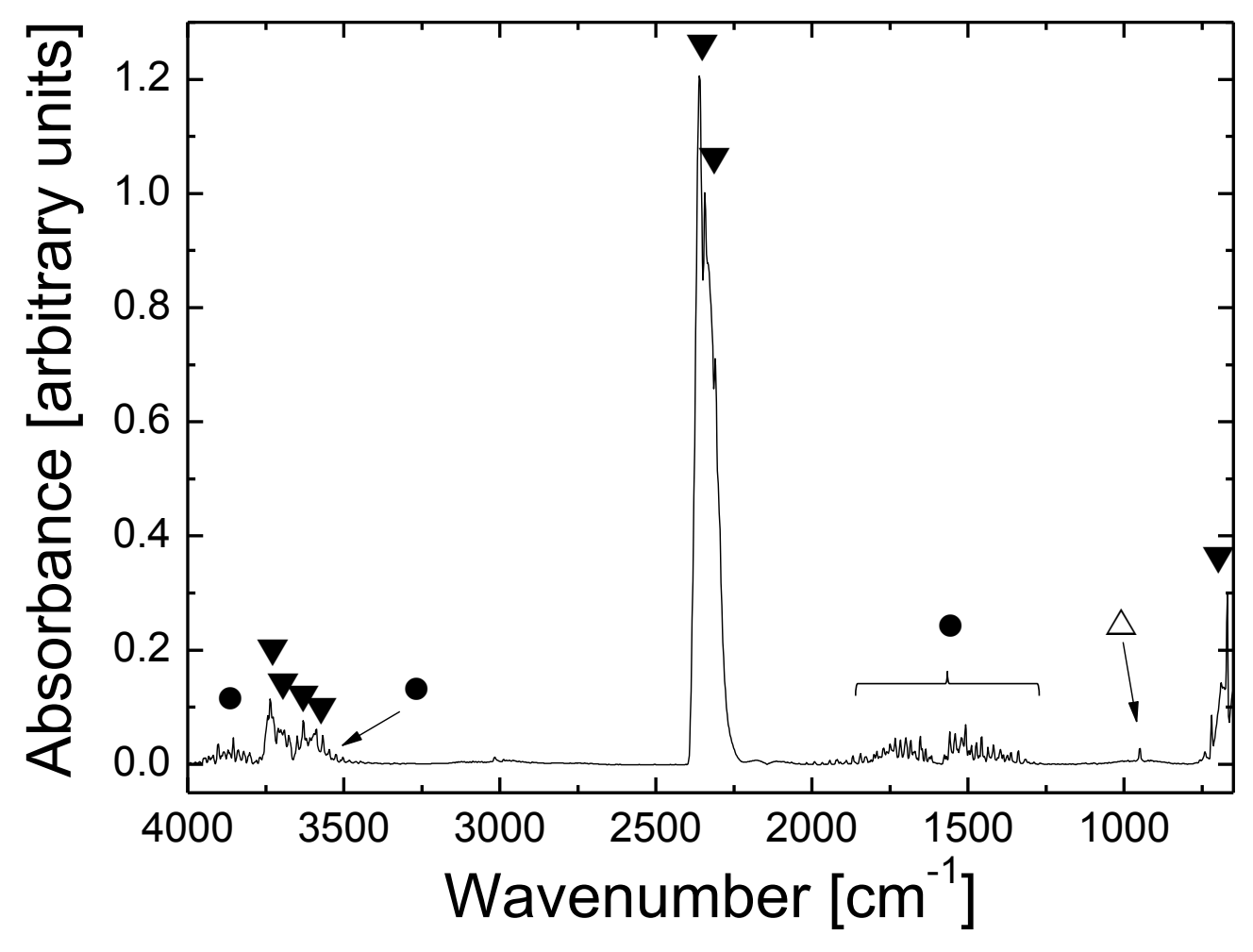

Figure 9 


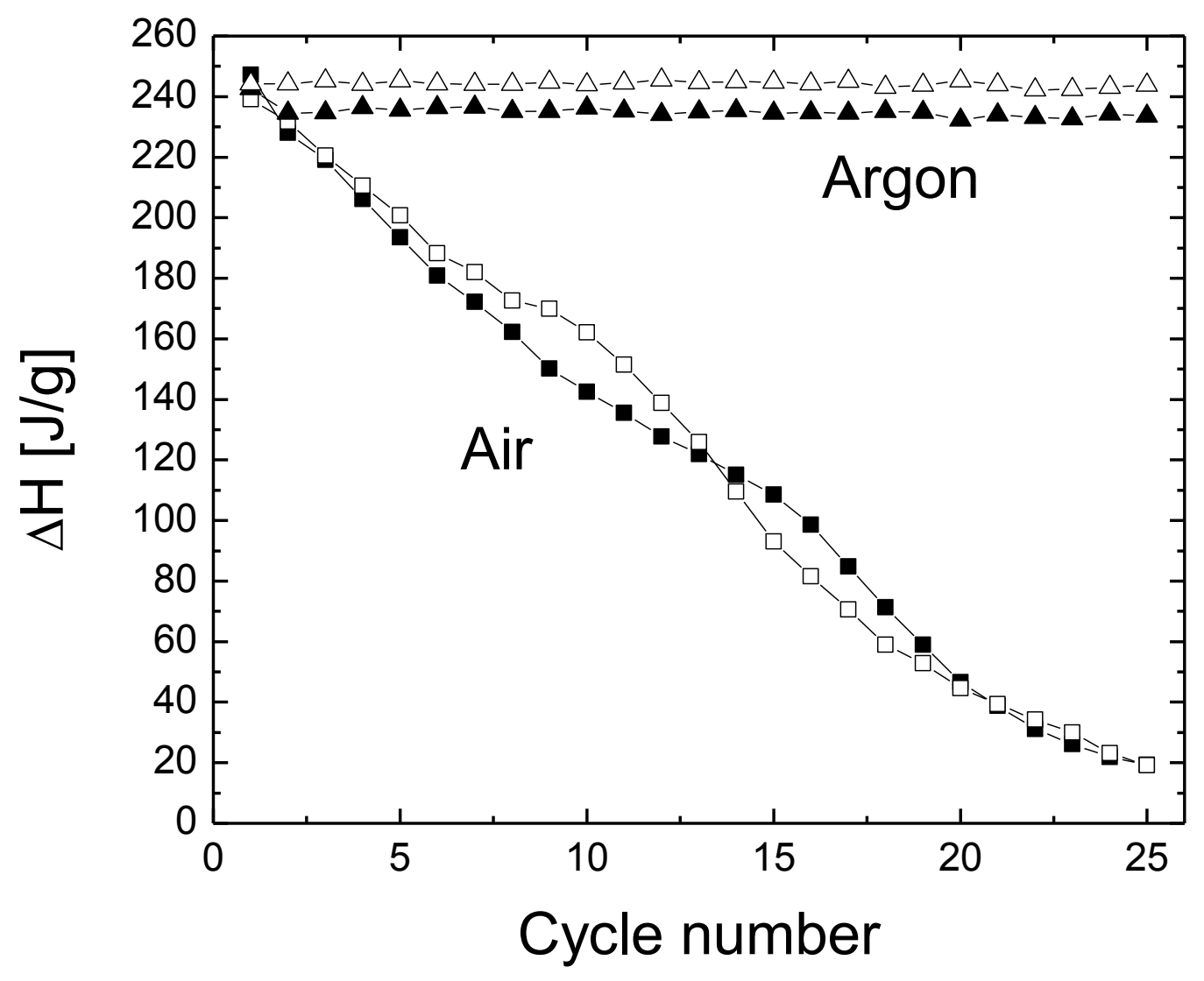

Figure 10 


\section{Supplementary files}
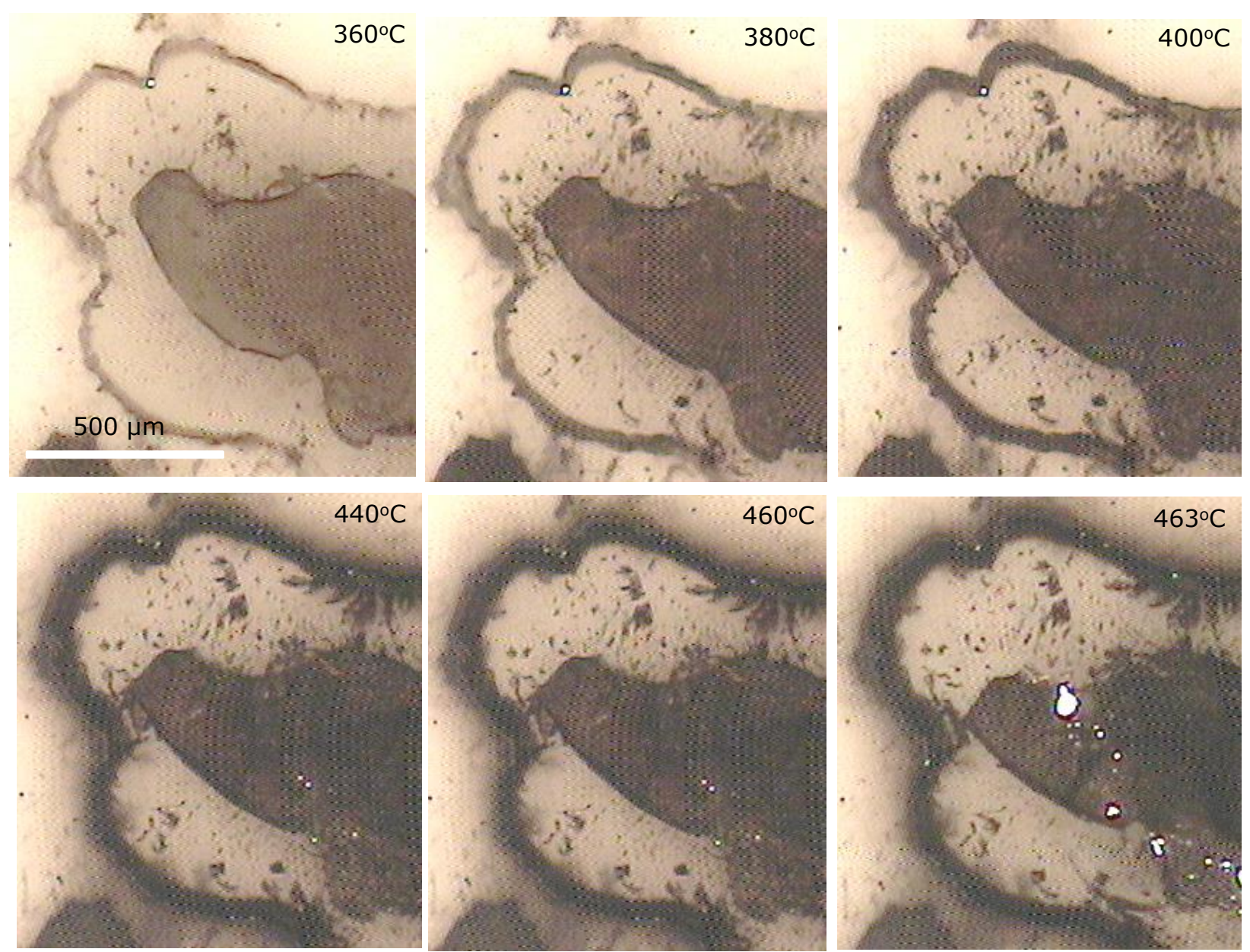

Figure S1: In-situ, hot stage optical microscope images (detail) of the Na-propionate sample heated in argon. The same magnification was used for all images. 

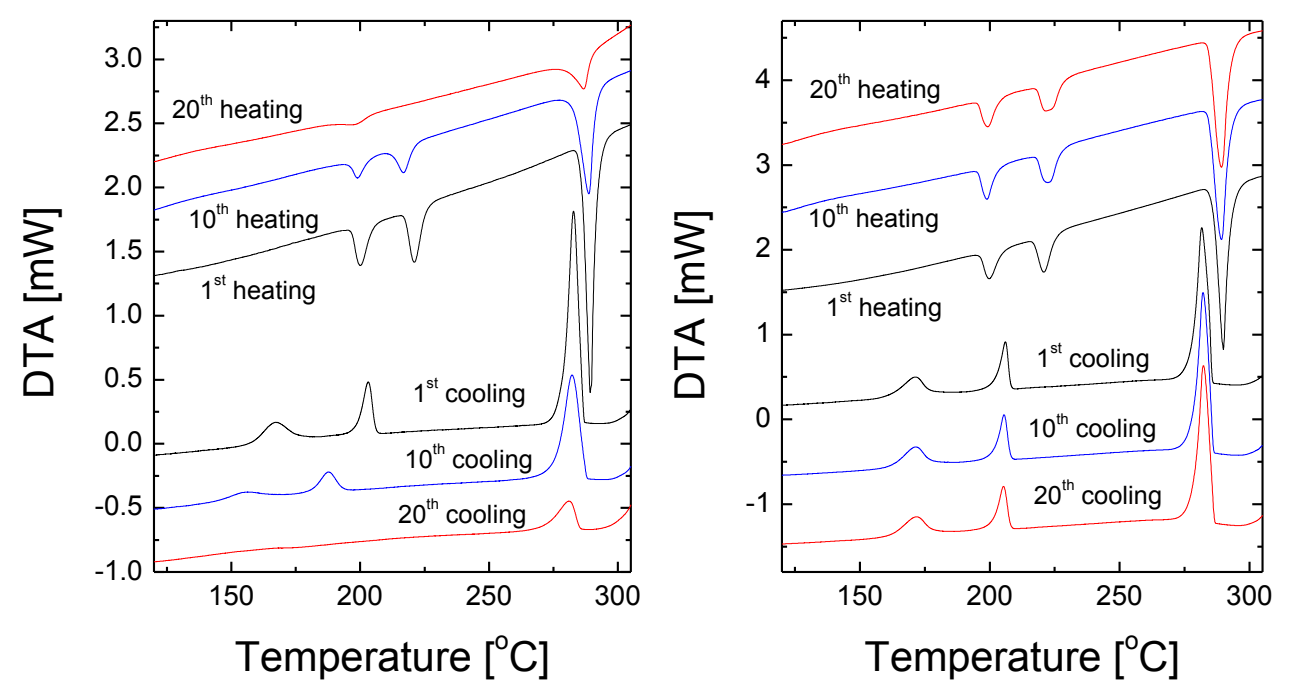

Figure S2: Selected DTA traces from the cycling experiments in air (left) and in argon (right). Exothermic upwards / Endothermic downwards. 